\title{
MISOGINIA Y EXCULPACIÓN: EL CANTO A TERESA
}

\author{
RUSSELl P. SEBOLD \\ Académico Correspondiente, \\ Real Academia Española
}

El lector medio, si recuerda algo del Canto a Teresa (1840), de Espronceda, largos años después de haberlo leído, conservará en la memoria la sensación de un desgarrador dolor, que tiene, empero, algo de hermoso, acaso por la nostalgia con que se asocia; sensación dolorosa y belleza que vuelven a la conciencia en las alas de una maravillosa melodía. Eso sí, no deja de haber asimismo una remembranza algo vaga del sufrimiento de una mujer singular y de un hombre que oscila entre la euforia y la indignación. Pocos lectores, por mucho tiempo que haga de su lectura del Canto a Teresa, tendrán una impresión tan confusa sobre la protagonista del poema como cierta alumna, a quien nunca pude apear de su convicción de que era Santa Teresa de Jesús. Sin embargo, esta obra de Espronceda es tal, que ni al estudioso habitual de la literatura le basta para su comprensión una simple lectura o relectura, sin el acompañamiento de ciertos datos extratextuales. Encaminémonos hacia un entendimiento más claro del contenido, arte y género del Canto a Teresa preguntando, primero, por la identidad del hombre que está, ya eufórico, ya indignado. ¿Quién hace uso de los verbos primopersonales a lo largo del poema? Porque el yo es la persona gramatical más adecuada para la expresión de la euforia y la indignación románticas.

El Canto a Teresa es un poema ni breve ni largo, de cuarenta y cuatro octavas reales, encuadrado, según es sabido, como canto II, en otra obra poética más extensa, de Espronceda, titulada El diablo mundo. Y como, hacia el final del canto I del poema extenso, se anuncia que un humilde anciano se levantará joven otra vez de su lecho, para «lanzarse al mundo de su dicha ufano, / rico de la esperanza que le encanta» ${ }^{1}$, un lector im-

\footnotetext{
1 José DE ESPRONCEDA, El estudiante de Salamanca. El diablo mundo, ed. de Robert Marrast, Clásicos Castalia, 81, Madrid, Editorial Castalia, 1978, p. 214, vv. 1382-1383. Normalmente, las referencias a otras citas de esta edición se indicarán insertando los números de las páginas y los versos en el texto, entre paréntesis, así: (p. 214, vv. 13821383). Sin embargo, en algunos casos ha resultado más cómodo y claro aludir a las octavas por sus números en el conjunto de cuarenta y cuatro octavas reales.
} 
paciente que no se tomara la molestia de leer notas al pie de la página, pudiera muy bien tomar el yo que se encarga del nuevo canto, a partir de la primera octava, por el del viejo Adán rejuvenecido. ¿O pertenece ese yo al narrador Espronceda - pues el de este guía nuestro tampoco escasea en las páginas anteriores-, o bien a algún personaje nuevo del canto II? Un lector más habituado a las ediciones cuidadas y fieles, en cambio, no se saltaría la nota del autor cuya llamada, desde las ediciones antiguas, está pegada al número romano II, a la cabeza del canto ${ }^{2}$. La aludida nota, en las ediciones antiguas y en la inmensa mayoría de las actuales, reza así: «Este canto es un desahogo de mi corazón; sáltelo el que no quiera leerlo sin escrúpulo, pues no está ligado de manera alguna con el Poema (N. del A.)»(p. 221). En fin: es el autor quien hace uso de la primera persona para dirigirnos la palabra en el Canto II, pero ahora será el autor como personaje, personaje autobiográfico. El hecho de que Espronceda se dramatice como personaje se revela ya por el estilo retórico de su nota al pie: desahogo de mi corazón.

Marrast reproduce, además, la versión primitiva de la nota, que se halla en el borrador autógrafo del Canto a Teresa; texto que resulta aun más iluminador para apreciar el sentido dramático con que el personaje autobiográfico mira su existencia: «Este canto $2 .^{\circ}$ es un desahogo de mi corazón - dice- Tal vez mis quejas parezcan fastidiosas y fuera de propósito a mis lectores. Yo tenía necesidad de escribir así, y he obedecido a un impulso superior a mi voluntad. Pongo aquí esta nota para que el que no quiera leerlo lo salte sin escrúpulo, pues no está ligado de ninguna manera a la historia general del cuento» (ibíd.). Ya está en su lugar la referencia al desahogo de mi corazón. Es más: en la versión primitiva de la nota, la pena se encarece por el hecho de que hablando de ella el poeta incluso está dispuesto a arriesgar la mala recepción del poema interpolado por los lectores $\mathrm{y}$, aparentemente, del poema largo también. Pero, pase lo que pase, expresarse así es una necesidad, emocional, se entiende; y satisfacer a semejante necesidad es obedecer a un impulso superior a mi voluntad. Impulso del yo que no pocas veces lleva a los románticos más allá de lo que conscientemente desean: amores más crueles que sublimes, encuentros desastrosos con los rivales en la liza literaria, peligros de la guerra, enfrentamientos con la misma sociedad que ellos se proponían salvar del oprobio, excesivos placeres sensuales que llevan a la pérdida de la juventud antes de su término natural. Son varias las aflicciones de las que quiere Espronceda desahogarse o aliviarse, pero todas ellas se reúnen simbólicamente en las emociones que le suscita el antiguo objeto de su amor, mencionado en el título del canto II de El diablo mundo.

\footnotetext{
${ }^{2} \mathrm{Al}$ escribir esto, miro la página 99 de la edición de I. Boix, Madrid, 1841, donde la ya mencionada llamada ocupa el mismo sitio que en la edición de Marrast.
} 
Preguntemos, así, quién es Teresa; pero por de pronto hagamos la pregunta y respondámosla a nivel puramente poético. Volveremos más tarde sobre la relación entre la historia general del cuento y el Canto II, y sobre la relación entre el personaje autobiográfico de este canto y el protagonista de la historia general; pues el decir Espronceda que no existe tal ligazón es simplemente una ironía coquetona. ¿Quién es, pues, Teresa? ¿Qué le ha pasado a Teresa para que el poeta le dedicara tan sentido desahogo? Teresa ha muerto de una calentura horrible, que le deformó la bella cara. Espronceda se imagina las postrimerías de su antigua amada, pues no fue de hecho testigo de ellas: Moriste, «ipobre Teresa! - le dice el poeta-, cuando ya tus ojos / áridos ni una lágrima brotaban, / cuando ya su color tus labios rojos / en cárdenos matices cambiaban, / cuando de tu dolor tristes despojos / la vida y su ilusión te abandonaban / y consumía lenta calentura / tu corazón al par de tu amargura» (pp. 236-237, vv. 1804-1811). Calentura, una de cuyas causas fue acaso una enfermedad venérea por lo que se verá más adelante. Y fue una muerte solitaria: «tu triste soledad y tu aislamiento» son otras circunstancias de ese trance de las que toma nota Espronceda en la octava siguiente (p. 237, v. 1815). Preguntemos cómo ha evolucionado el personaje Teresa en la versión literaria de sus amores que nos ha dejado Espronceda. Pues es la única forma de desandar sus pasos y descubrir el camino que la condujo a tan deplorable óbito.

Era inocente Teresa cuando se conocieron. Lo era también el futuro cantor de las cuitas de la señorita Mancha. «Que yo como una flor que en la mañana / abre su cáliz al naciente día - le dice Espronceda a Teresa-, / ¡ay! al amor abrí tu alma temprana, / y exalté tu inocente fantasía, / yo inocente también; ¡oh! ¡cuán ufana / al porvenir mi mente sonreía, / y en alas de mi amor con cuánto anhelo / pensé contigo remontarme al cielo!» (p. 236, vv. 1788-1795). Era Teresa como un personaje de libro de caballerías: «iay! arrancada de sus patrios lares, / joven cautiva», que un caballero andante acaso sueñe con rescatar «del gótico castillo», o que un trovador aspire a cantar acompañándose en el arpa (p. 225, vv. 1556-1563), Por su atractivo sencillo y puro, la belleza de la Teresa joven parecía fundirse con la de la naturaleza. Era «la forma bella que cruzó gallarda, / allá en la noche, entre el medroso velo» (p. 225, vv. 166-1567). Amarla era como participar en la sublime conversación de los místicos con Dios, que levanta a sus interlocutores humanos hacia sí: «Hay una voz secreta, un dulce canto, / que el alma sólo recogida entiende; / un sentimiento misterioso y santo, / que del barro al espíritu desprende» (p. 226, vv. 15801583). ¿Hablaba la naturaleza, o hablaba Teresa? Ni el propio amante distinguía entre una voz y otra: "oír pensaba el armonioso acento / de una mujer, al suspirar del viento» (p. 226, vv. 1594-1595). Mas donde se perfecciona la comparación de la Teresa pura con la naturaleza pura, es en las octavas 13 y 14 , que no tienen pareja en toda la poesía lírica: 


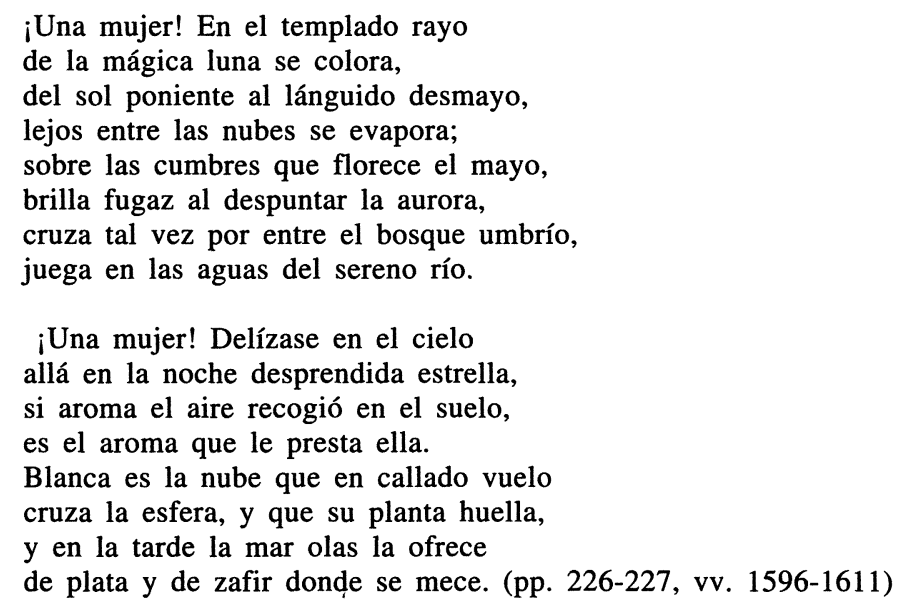

Ora una nube, ora una figura entre humana y sobrenatural, Teresa juega en las aguas del río, como lo hará en la fuente de los Álamos la mujer fantástica de quien se enamora con fatales consecuencias el primogénito de los marqueses de Almenar en Los ojos verdes, de Bécquer. Teresa es una estrella que se desliza libre y gloriosa por los cielos. $\mathrm{Y}$ al inicio de la estrofa que sigue a las dos copiadas hace un momento, se la describe como «Mujer que amor en su ilusión figura; / mujer que nada dice a los sentidos» (p. 227, vv. 1612-1613), es decir, icono de la mujer perfecta elaborado por la imaginación del poeta, esencia, concepto del amor, más bien que mujer de carne y hueso. Es incorpórea, fugaz y transparente, como la ya mencionada mujer fantástica de Los ojos verdes, o bien, como la tercera de las tres mujeres que se le presentarán a Gustavo Adolfo en su rima XI: «-Yo soy un sueño, un imposible, / vano fantasma de niebla y luz; / soy incorpórea, soy intangible; / no puedo amarte. - iOh, ven; ven tú!» ${ }^{3}$. En las octavas 13 a 15 del Canto a Teresa, alienta ya la llamada mujer ideal de Bécquer, y queda claro por estos y otros versos que las Rimas becquerianas, sin Espronceda, hubieran sido menos posibles.

Pero nos hemos referido a la evolución de la casi seráfica Teresa de las primeras octavas, y es hora de que recojamos este tema. Espronceda vuelve a llamar a Teresa estrella o astro, al preguntarle: «¿Cómo caíste despeñado al suelo, / astro de la mañana luminoso? / Ángel de luz, ¿quién te arrojó del cielo / a este valle de lágrimas odioso?» (p. 231, vv. 17001703). La bella imagen de la primera Teresa que nos pintaba Espronceda, ¿es quizá más ficticia que fiel a la vida? Miremos algunos pasajes no examinados antes. En estos versos se nos dice que se trata de una simple

${ }^{3}$ Gustavo Adolfo BÉCQuer, Rimas, ed. de Russell P. Sebold, Clásicos Castellanos, serie nueva, 22, Madrid, Espasa Calpe, 1991, p. 211. 
mujer y unos simples goces «que engalana la rica fantasía, / goces que avaro el corazón ansía» (p. 226, vv. 1594-1595). Pues, en fin, «esa mujer tan cándida y tan bella / es mentida ilusión de la esperanza. / Es el alma que vívida destella / su luz al mundo cuando en él se lanza, / y el mundo con su magia y galanura, / es espejo no más de su hermosura» (ibíd., vv. 1622-1627). Atención: el alma que destella, reflejándose su hermosura en la naturaleza, así como en la mujer fantástica, es la del poeta, no la de Teresa. En la imagen femenina que se nos ha expuesto, hay a la par elementos de mitología y leyenda: «Es el amor que al mismo amor adora, I el que creó las sílfides y ondinas, / la sacra ninfa que bordando mora / debajo de las aguas cristalinas» (p. 227, vv. 1628-1631).

Espronceda ha estado pintando a su propia alma, o bien la personificación de una aspiración de su alma. Una mujer como la Teresa ideal es la que el enamorado vislumbra, «volando tras la imagen peregrina / el corazón de su ilusión divina» (p. 226, vv. 1586-1587). Las sílfides, las ondinas, la ninfa que borda debajo de las aguas, la mujer de la fuente de los Álamos, de Bécquer, son otras personificaciones o símbolos del alma romántica enamorada de sí misma. Pero todo esto lo dice más claramente Espronceda en el ya citado verso: Es el amor que al mismo amor adora. El romántico se ama a sí en la mujer. Ya en 1771, el personaje Tediato, de Cadalso, estaba de luto por sus perdidas aspiraciones amorosas más bien que por la muerte de su amada de carne y hueso, y en el cadáver de ésta no buscaba sino una imagen o símbolo de esas ilusiones destruidas.

Pero volvamos a la pregunta de Espronceda a Teresa: ¿Cómo caíste? ¿Cómo, en qué sentido, cayó Teresa? ¿Cuál es la acepción del verbo caer en el poema? Hacia el final del Canto, donde se trata de la muerte de Teresa, el poeta se dirige a ella y exclama: «iEspantosa expiación de tu pecado!» (p. 237, v. 1829). Fue así moral la caída de Teresa. Tu pecado, dice Espronceda. ¿Cuál es este pecado? Su índole se revela en parte por la intervención en la obra de unos personajes pequeños. ¿Quiénes son? Advierte Espronceda a la pecadora de que «tus hijos ;ay! de ti se avergonzaran, / y hasta el nombre de madre te negaran» (p. 234, vv. 1762-1763). Muy cerca del final, el antiguo amante de Teresa vuelve sobre lo mismo: «tus hijos jay! en tu postrer momento, / a otra mujer tal vez acariciando, / madre tal vez a otra mujer llamando» (p. 237, vv. 1817-1819). Y en la próxima octava el poeta la imagina «buscando en vano con los ojos fijos / y extendiendo tus brazos a tus hijos» (p. 238, vv. 1834-1835). En los tres pasajes sobre estos párvulos, fijémonos en el posesivo tus. Acudamos ahora a la historia, el texto biográfico, con la finalidad de aclarar el discurso poético. Fijémonos, decía, en el posesivo tus. Estos hijos son de Teresa, mas no son de Espronceda. Mejor dicho: solamente una - Blanca de Espronceda- es del poeta; los demás son de otros señores.

En el penúltimo pasaje sobre los pequeñuelos: a otra mujer tal vez 
acariciando, / madre tal vez a otra mujer llamando, se sugiere la presencia de otro personaje femenino y también de otro personaje masculino, pues donde hay una madre, o una segunda madre, suele haber un padre. Se trata del padre de los dos primeros hijos de Teresa, a quien Espronceda miraba como rival por el afecto de ésta. Entonces, ¿cuál fue el pecado de Teresa? Además de las inconfundibles circunstancias que se nos van aclarando, también se descubre la naturaleza del pecado de Teresa por su nombre completo: Teresa Mancha de Bayo. De Bayo. Teresa estaba casada con otro señor al entregarse a la gran pasión de su vida: José de Espronceda. $\mathrm{Su}$ pecado fue el adulterio. Reconstruyamos en parte la historia amorosa de Espronceda y Teresa.

¿Cuáles fueron las circunstancias en que se cometió tan horrendo pecado por vez primera? ¿Se amaron esa vez en España el poeta y Teresa? Preguntas cuyas respuestas más claras se hallan en la historia, también están, sin embargo, contestadás en forma alusiva en el poema que comentamos. Consideremos los cuatro primeros endecasílabos de la octava 12: «Yo desterrado en extranjera playa / con los ojos, extático seguía / la nave audaz que en argentada raya / volaba al puerto de la patria mía» (p. 226, vv. 1588-1591). Mas Espronceda encontrará pronto un hermoso solaz de su añoranza de España en esa playa extranjera, que era la de Albión. ¿Por qué asocia Espronceda la imagen del destierro con su gran amor por Teresa? Durante el reinado del reaccionario Fernando VII, por motivos políticos, el coronel Epifanio Mancha, militar liberal, y sus hijas vivían desterrados en Londres. Las hijas bordaban brazaletes para ayudar a sostener a la familia. En tan honrada pobreza, mientras era todavía soltera Teresa, entre 1827 y 1829 , en la capital británica, debieron de conocerse ella y su gran amor, Espronceda, joven dandy, también desterrado por sus ideas liberales. Junto con su mejor amigo, Patricio de la Escosura, y otros jóvenes, Espronceda había fundado Los Numantinos, una sociedad secreta antiabsolutista. Y ahora aprovechaba su destierro político para hacer el grand tour d'Europe. Su actitud alegre y despreocupada de dandy en el tour de los diversos países se ejemplifica por su llegada a Lisboa. No le quedaba sino un duro; el impuesto de sanidad que le cobraron fue de tres pesetas, y las dos restantes las tiró al río Tajo, porque, decía, no quería entrar en tan gran ciudad con tan poco dinero. (Podía permitirse tal lujo, porque en todas las ciudades que visitaba le esperaban generosas libranzas de su madre.)

Aparentemente en 1830, para remediar la pobreza de su familia, Teresa se casó con don Gregorio de Bayo, hijo de una familia de ricos comerciantes de Bilbao, quien hacía frecuentes viajes de negocios a Inglaterra. Con Bayo Teresa tuvo inmediatamente dos hijos. Luego Teresa abandonó a su marido y a sus hijos, y en marzo de 1833 siguió a Espronceda a Madrid. Espronceda le puso a Teresa una casa aparte, y por guardar las 
apariencias él siguió viviendo con su madre. Nació en 1834 Blanca, la hija de Teresa y el poeta. Dos años más tarde, en 1836, Teresa dejó a Espronceda, dolida de sus frecuentes y largas ausencias y, sobre todo, de sus jactancias de conquistador de otras mujeres. La señora de Bayo murió en 1839, y Espronceda fue a ver su cadáver por una ventana de sótano en el número 22 de la calle de Santa Isabel, escuálida pocilga donde, el 18 de septiembre de 1839, con un vómito de sangre acabó su caída el antiguo astro del amor ideal ${ }^{4}$.

Hemos utilizado ahora información extrapoética para demostrar el carácter autobiográfico del Canto a Teresa, y es así un momento oportuno para introducir una breve digresión cuyo propósito es mostrar que el elemento de autobiografía presente en el poema se extiende más allá de los amores del poeta y la esposa de Gregorio de Bayo. Las caras esenciales de la vida de todo poeta romántico son la amorosa y la literaria; y como esta última también se halla incorporada al Canto a Teresa en la forma de alusiones a otras obras de Espronceda, puede decirse que, por lo menos a nivel simbólico, el poema es una auténtica y cabal autobiografía. En un símil de la octava 4 del Canto a Teresa, aparece una «guerrera nave / [...] / y al mar dejando que a sus pies alabe / su triunfo en roncos cantos, va velera, / una ola tras otra bramadora / hollando y dividiendo vencedora»; versos que recuerdan el comienzo de la Canción del pirata (1835): «Con diez cañones por banda, / viento en popa, a toda vela, / no corta el mar, sino vuela / un velero bergantín» ${ }^{5}$. En la octava 8 , citada en parte antes, Espronceda evoca comparativamente una doncella de la Edad Media y «del gótico castillo el altanero / antiguo torreón, do sus pesares / cantó tal vez con eco lastimero, / ¡ay, arrancada de sus patrios lares, / joven cautiva, al rayo de la luna, / lamentando su ausencia y su fortuna»; trozo que es al mismo tiempo una remembranza de la gran novela histórica romántica de

${ }^{4}$ En relación con estos datos, pueden consultarse las fuentes siguientes: Enrique RoDRÍGUEZ-SOLÍs, Espronceda. Su tiempo, su vida y sus obras, Madrid, Imprenta de Fernando Cao y Domingo de Val, 1884; José CASCALES MuÑoz, D. José de Espronceda. Su época, su vida y sus obras, Madrid, Biblioteca Hispana, 1914; José CASCALES MUÑOZ, El auténtico Espronceda pornográfico y el apócrifo en general, edición especial de 300 ejemplares para bibliófilos, Toledo, Imprenta del Colegio de Huérfanos, 1932: Narciso ALONSO CORTÉs, Espronceda. Ilustraciones biográficas y críticas, 2." ed., Valladolid, Librería Santarén, 1945; Vicente LlORENS, Liberales y románticos, 2. ${ }^{a}$ ed., Madrid, Castalia, 1968; Robert MARRAST, José de Espronceda et son temps, París, Éditions Klincksieck, 1974; Pedro ORTIZ ARMENGOL, Espronceda y los gendarmes, Madrid, Editorial Prensa Española, 1969; Jorge CAMPOS, «Introducción. Vida y obra de José de Espronceda», en Espronceda, Obras completas, Biblioteca de Autores Españoles, 72 , Madrid, Atlas, 1954; y José María PEMÁN, Espronceda, Madrid, Editorial Sucesores de Rivadeneyra, 1966. Los libros de Casalduero sobre Espronceda contienen escasísima información biográfica.

5 José DE ESPRONCEDA, Poesías líricas y fragmentos épicos, ed. de Robert Marrast, Clásicos Castalia, 20, Madrid, Castalia, 1970, p. 225. 
Espronceda, Sancho Saldaña o el castellano de Cuéllar (1834), pues en esta obra el satánico protagonista tiene cautiva en un torreón de su castillo a Leonor de Íscar, a quien se propone llevar al altar por la fuerza. Y otra muestra que el lector ya conoce: «Yo, desterrado en extranjera playa, / con los ojos extáticos seguía / la nave audaz que en argentada raya / volaba al puerto de la patria mía» (octava 12), que, además de localizar a Espronceda en Londres cuando empezaron sus amores con Teresa, forma un eco de su poema La entrada del invierno en Londres (1827): «Mas ¡ay! yo triste, de continuo lloro / [...] / el ponto inmenso viendo / que me encadena entre el Bretón sombrío, / y cuyas turbias olas / me alejan de las costas españolas» ${ }^{6}$.

Completemos ahora, en forma poética, la evolución de la antes inocente y bella Teresa Mancha. No le quedaba ya a la antigua mujer celestial, mujer de ensueño de Espronceda, aspiración a más futuro con él. «Los años ¡ay! de la ilusión pasaron; / las dulces esperanzas que trajeron / con sus blancos ensueños se llevaron, / y el porvenir de oscuridad se vistieron» (pp. 232-233, vv. 1732-1735). Por el camino del pecado y la inmoralidad, la decadencia va de mal en peor, de espiritual en física. Apenas queda alguna remembranza verbal del delicado encanto de la bordadora de Londres: «Roída de recuerdos de amargura, / árido el corazón sin ilusiones, / la delicada flor de tu hermosura / ajaron del dolor los aquilones; / sola, y envilecida, y sin ventura, / tu corazón secaron las pasiones» (p. 234, vv. 1756-1761). ¿Qué pasiones son estas que le secaron el corazón? Son las de los sucesores de Espronceda en el amor adulterino con Teresa, que le pagarían su amor ya solamente físico ${ }^{7}$. Porque la pobre no disponía de otros medios para vivir, y por ello quedó reducida a habitar un sótano. En los dos trozos del poema que acabamos de citar, le queda a la desventurada mujer un vago recuerdo de la felicidad de otros tiempos, representado por los sustantivos ilusión, esperanzas, ensueños, ilusiones, flor y hermosura. Mas en el último fragmento descriptivo sobre Teresa contenido en el poema se acusa una decadencia física y psicológica total, y de reminiscencias de la dorada mañana de la vida no resta ninguna. He aquí el trozo aludido: «Tus mismas manos de dolor mordiendo!» (p. 238, v. 1832). Está la pobre calenturienta, delirante, loca, con voluntad al parecer de destruirse a sí misma.

¿Cómo representa Espronceda su propia trayectoria de amante en el

6 Ibid., p. 129.

7 Sobre la vida de Teresa después de su separación de Espronceda, Rodríguez-Solís escribe: «Hermosa como era, muchos hombres la galantearon, entre ellos algunos amigos de Espronceda, que parece ser ley que en amor no haya amigos para amigos. Los celos de Teresa llegaron a tal grado de exaltación, que ofreció a uno de esos amigos de su amante huir con él si mataba a Espronceda» (Espronceda. Su tiempo, su vida y sus obras, p. 154). Véanse asimismo las notas de tema relacionado más abajo. 
Canto a Teresa? En su concepto idealizado de la juventud de Teresa, hay cierta influencia de Rousseau - Teresa era buena mientras era reflejo de la naturaleza-; mas para presentar la propia juventud, Espronceda no recurre ya al simbolismo del buen salvaje en el mundo natural, sino que echa mano de la entonces manida idea de que en la época más remota de la historia de Occidente, en el Medievo, existía cierta nobleza, cierto idealismo incorrupto: «soñaba al héroe ya, la plebe atenta / en mi voz escuchaba su destino, / ya al caballero, al trovador soñaba / y de gloria y de amores suspiraba» (p. 225, vv. 1576-1579). Mas tanto idealismo, tanta emulación de los inspirados adalides medievales, estaba destinada a concluir en la más consumada desilusión y en una de las más elocuentes expresiones del fastidio universal - por usar del término de Meléndez Valdés- que existe en toda la historia del romanticismo, no sólo español, sino mundial. Me refiero a las dos últimas octavas reales, del Canto a Teresa. Miremos la primera de ellas:

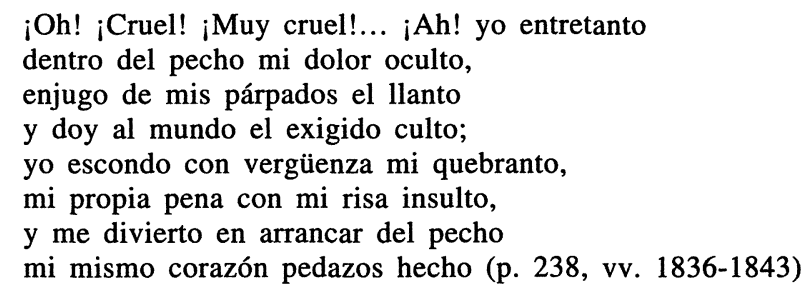

Detrás de la risueña fachada del poeta, hay un vacío que tiene las proporciones de un abismo. Pero es más que un vacío. Con esta voz se denota una ausencia de materia, espíritu o fuerza, mas el fenómeno que se da en Espronceda es a la vez corrosivo, mordaz; un dolor que le come, le consume el corazón, dejándole un hueco en el pecho. Son especialmente notables los dos endecasílabos finales de la octava real que acábase de citar: y me divierto en arrancar del pecho / mi mismo corazón pedazos hecho. Compárese este pasaje con otro anterior (vv. 1724-1727), en el que el poeta habla con los lectores: «Huid, si no queréis que llegue un día / en que enredado en retorcidos lazos / el corazón, con bárbara porfía / luchéis por arrancároslo a pedazos» (p. 232). Parece acerba parodia de estos pasajes el siguiente poema del norteamericano Stephen Crane (1871-1900):

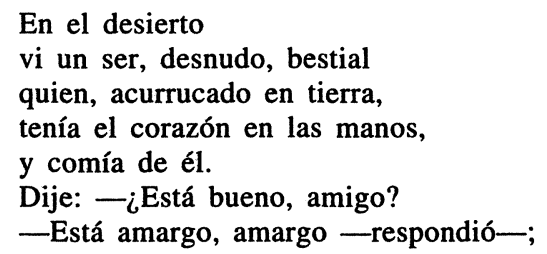


pero me gusta

porque es amargo,

y porque es mi corazón ${ }^{8}$. tima:

Miremos ya la octava final, y consideremos su relación con la penúl-

\author{
Gocemos, sí; la cristalina esfera \\ gira bañada en luz: ¡bella es la vida! \\ ¿Quién a parar alcanza la carrera \\ del mundo hermoso que al placer convida? \\ Brilla radiante el sol, la primavera \\ los campos pinta en la estación florida: \\ truéquese en risa mi dolor profundo... \\ Que haya un cadáver más, iqué le importa al mundo! \\ (pp. 238-239, vv. 1844-1851)
}

La hermosura del mundo, el brillo del sol, las flores de la primavera, son la fachada de otro vacío; son en gran escala lo mismo que la risa del poeta en pequeña escala, y en ninguno de los dos casos hay nada sustancial detrás. El hecho de que el mundo parezca un vacío para Espronceda se confirma por el epígrafe que escogió para el Canto a Teresa. Trátase de la siguiente octava real del poema María (1840), de su amigo Miguel de los Santos Álvarez: «Bueno es el mundo. ¡Bueno! ¡Bueno! ¡Bueno! / como de Dios al fin obra maestra, / por todas partes de delicias lleno, / de que Dios ama al hombre, hermosa muestra! / iSalga la voz, alegre, de mi seno / a celebrar esta vivienda nuestra! / ¡Paz a los hombres! ¡Gloria en las alturas! / ¡Cantad en vuestra jaula, criaturas!» ${ }^{9}$.

En estos versos del amigo de Espronceda, el mundo se representa como una jaula para sus habitantes; ¿y qué es una jaula sino un paréntesis, un intervalo, un vacío en la vida normal de quienes se ven forzados a habitarla? En fin: el mundo es un vacío; un cadáver es otro vacío, ¿y qué puede importar un vacío a otro vacío? "Que haya un cadáver más, iqué importa al mundo!» No ha habido nunca más profunda ni más elocuente expresión del nihilismo, del fastidio universal. Ni quizá mejor ejemplo de esa muy romántica teatralización de la propia emoción ${ }^{10}$.

8 «In the desert / I saw a creature, naked, bestial, / who, squatting upon the ground, / held his heart in his hands, / and ate of it. / I said, "Is it good, friend?" / "It is bitter, bitter," he answered; "but I like it / because it is bitter, / and because it is my heart"” (en The Portable Stephen Crane, ed. Joseph Katz, Nueva York, Penguin Books, 1969, p. 536).

9 En Espronceda, El diablo mundo, ed. de Marrast, debajo del título del Canto II, A Teresa. Descansa en paz, y a la cabeza del texto del indicado canto, p. 221. Miguel de LOS SANTOS ÁlVAREZ, María, Madrid, En el Gabinete Literario, 1840, p. 65.

10 Véase Russell P. SEBOLD, «Introducción: El desconsolado sentir romántico», Trayectoria del romanticismo español. Desde la Ilustración hasta Bécquer, Filología, 10, Barcelona, Editorial Crítica, 1983, pp. 14-16. 
Paralelamente con la caída de la pecadora Teresa y la pena del poeta, ha evolucionado la visión de la naturaleza, que es el fundamento de la metafísica y todas las metáforas de la poesía romántica. Ya en la primera mitad del siglo XVIII pensadores como Montesquieu y Feijoo teorizaban acerca del influjo de los terrenos y los climas sobre la conducta del hombre, pero después Rousseau también conectaría nuestras emociones y carácter moral con la naturaleza. De ahí que en el Canto a Teresa, ya por impulsos positivos, ya por otros negativos, la naturaleza parezca siempre asociarse con las mutaciones de fortuna de los personajes y a la vez reflejar las reacciones emocionales de los amantes ante esos cambios. El estilo poético neoclásico, símbolo muchas veces del optimismo de la Ilustración, es aprovechado aquí para captar la tonalidad expansiva de Espronceda en el pleno optimismo de su juventud, por ejemplo, en estos endecasílabos pertenecientes a las octavas reales segunda y tercera del Canto a Teresa: «Imágenes de oro bullidoras, / sus alas de carmín y nieve pura / al sol de mi esperanza desplegando, / pasaban, jay! a mi alrededor cantando. // Gorjeaban los dulces ruiseñores, / el sol iluminaba mi alegría, / el aura susurraba entre las flores, / el bosque mansamente respondía, / las fuentes murmuraban sus amores» (p. 223, vv. 1512-1520). Algunas de las preciosas octavas sobre el amor que quedan citadas en páginas anteriores también simbolizan por sus armoniosas metáforas naturalistas el optimismo y la ilusión amorosa; y semejantes vistas de la naturaleza son, le dice Espronceda a Teresa, «el cuadro ${ }^{11}$ de tus breves glorias» (p. 237, v. 1820).

En cambio, el desenlace de los amores del poeta y la mujer de Bayo se acompaña por otra visión muy diferente de la naturaleza. Es ya una auténtica naturaleza romántica: «las rosas del amor se marchitaron, / las flores en abrojos convirtieron, / y de afán tanto y tan soñada gloria / sólo quedó una tumba, una memoria» (p. 233, vv. 1736-1739). Fijémonos en el verbo convirtieron. Tan estrecha es la relación entre los románticos y el mundo natural, que no se trata simplemente de metáforas naturalistas para describir al interlocutor humano de la naturaleza; sino que cambia ésta al cambiar su compañero, y devienen la misma sustancia, en todo caso, sustancias de la misma tonalidad emocional. He aquí un artículo de fe que estaba en vigor desde el manifiesto romántico de Cadalso, de 1773: «En lúgubres cipreses / he visto convertidos / los pámpanos de Baco, / y de Venus los mirtos», etc. ${ }^{12}$

11 En el Canto a Teresa, aparte de la autobiografía, el tema son las costumbres amorosas, las transgresiones contra la institución del matrimonio, la decepción, la arrogancia, la falta de misericordia, y el término cuadro nos recuerda la presencia de este marcado elemento costumbrista en medio del poema lírico. Algunos estudiosos del romanticismo separan el costumbrismo completamente del movimiento romántico, pero la distinción teórica siempre falla en la práctica.

12 José De Cadalso, Poesías, en Poetas líricos del siglo XVIII, I, ed. de Leopoldo Augusto de Cueto, Biblioteca de Autores Españoles, 61, Madrid, Atlas, 1952, p. 275a 
¿Quién tiene la culpa de las transgresiones y desilusiones poetizadas en el Canto a Teresa? Es culpable la sociedad incompasiva y cruel, el «mundo», según se la llama en las octavas finales; y en otra estrofa Espronceda habla de la contienda entre la «mezquina sociedad» y la «turbulenta» Teresa que rompe las barreras del buen gusto (p. 235, 1772-1779). Mas, a nivel individual, ¿qué duda cabe que el mismo Espronceda es el más culpable? Él convenció a la pobre mujer de que dejara a su marido e hijos; fue el primero que la llevó por el camino del pecado; y luego, mientras estaba con ella, hacía el amor a otras mujeres. En fin: él la amó, la corrompió, la abandonó psicológicamente, antes que ella le abandonara físicamente, y ni aun la socorrió durante su última enfermedad. Para colmo, le echa en cara la vergüenza que sienten sus pequeños hijos. Es más: ya desde la octava del poema María, que colocó a la cabeza del Canto a Teresa, Espronceda está sacando a la vergüenza a su antiguo amor.

Pues ¿cuál es el tema de María y cómo se relaciona con la historia de Teresa? María era una linda y virtuosa adolescente, a quien un accidente mortal privó de sus padres; y la única parienta que podía amparar a la desventurada joven, era dueña de un prostíbulo. Por la hermosura de la niña, la parienta veía en ella una aventajada recluta para las tropas de Venus, pero año tras año María resistió a toda tentación, manteniéndose pura. Colocar un fragmento de este relato en el umbral del poema dedicado a Teresa era como decirle a ésta: Mira el ejemplo de esta niña que, rodeada del vicio, fue buena; y tú, en cambio, rodeada de la virtud -un marido que te amaba y dos niños que te adoraban-, optaste por ser mala. Pero en todo esto no hay que olvidar el papel del famoso poeta. Espronceda es el machista más aborrecible que cabe imaginarse. Con él sólo es comparable el poeta Gabriel García Tassara, que no quiso nunca ver a la niña que tuvo con Gertrudis Gómez de Avellaneda, negándose incluso a pagar los funerales de la pequeña, muerta a los seis meses de vida.

Sin embargo, es menester recordar que estamos en la primera mitad del siglo XIX. Antes de 1840, ni se habla de la «emancipación» de la mujer, y todavía en 1858, Rosalía de Castro observará que «el patrimonio de la mujer son los grillos de la esclavitud» ${ }^{13}$. Persiste, en esos años, en forma fuerte la tradición medieval de la mujer como tentadora, como descendiente de la primera tentadora, Eva; tradición religiosa y literaria inventada por los hombres. También se precisa recordar que Espronceda es otro Byron; y semejante dandy y calavera no va a reconocer nunca, en forma pública,

La cursiva es mía. Sobre el manifiesto romántico cadalsiano de 1773 , véase mi libro Cadalso: el primer romántico «europeo» de España, Biblioteca Románica Hispánica, 215, Madrid, Editorial Gredos, 1974, pp. 94-146.

${ }^{13}$ Lieders, publicado en El Álbum del Miño, en 1858, en Rosalía de Castro, Obras completas, ed. de Victoriano García Martí, Madrid, Aguilar, 1977, t. II, p. 949. Rosalía se casa y escribe esta protesta feminista en el mismo año. 
su propia culpa ${ }^{14}$. De acuerdo con los prejuicios de la época, la culpa la puede tener solamente esa pobre ciudadana de segunda clase: la mujer, que se dejó amar. Espronceda habla del pecado de Teresa, pero nunca del suyo propio. Estaba en pleno vigor ese criterio doble con que la hipócrita sociedad autorizaba para el hombre lo que condenaba para la mujer. Y Teresa ofende a esta mojigata sociedad: «Espíritu indomable, alma violenta, I en ti, mezquina sociedad, lanzada / a romper tus barreras turbulenta» (p. 235, vv. 1773-1775).

Quizá sea éste el problema principal para Espronceda. El hombre tiene derecho a ofender a la sociedad con el escándalo; y pese a ello, todavía tiene entrada en todas partes. En efecto, resulta más interesante tal hombre. Mas la mujer no goza del derecho de ofender a la sociedad, y la presencia de Teresa se le habrá convertido en espectáculo bochornoso a Espronceda y su familia. Con su magnífico canto necrológico, Espronceda quería, por ende, separarse moralmente de su antigua amante, tanto más cuanto que en sus últimos tiempos Teresa estaba amancebada con Narciso de la Escosura, hermano del mejor amigo del autor de El diablo mundo, Patricio de la Escosura ${ }^{15}$. ¿Cómo justifica Espronceda su crueldad con Teresa? Es decir, aparte de la justificación que le brinda el doble criterio moral de la sociedad. Pues bien, acude a una definición de la mujer absolutamente odiosa: «Mas jay! que es la mujer ángel caído / o mujer nada más y lodo inmundo, / hermoso ser para llorar nacido, / o vivir como autómata en el mundo» (pp. 231-232, vv. 1708-1711). Es como si el poeta le dijera a Teresa lo siguiente: ¡Qué suerte más buena tienes tú en haber podido llorar por mí! De otro modo, como mujer de Bayo, no serías sino autómata, porque ser ama de casa es ser autómata. Yo soy realmente un buen mozo en haberte salvado de la monotonía antipoética de la vida burguesa. Y esto me lo pagas robándome las ilusiones: «Un recuerdo de amor

${ }^{14}$ En el margen del borrador autógrafo del Canto a Teresa, comentando ciertos versos, Espronceda apuntó para sí mismo, no para el público: «Y mi amor te perdió» (Diablo, 236, nota 149). Sobre la expresión más o menos directa del arrepentimiento de Espronceda en otros poemas, véase mi artículo «Teresa, idea fija de Espronceda (en la estela del Canto a Teresa)», en Salina, núm. 14, 2000. El Canto a Teresa representa la visión de la desgraciada mujer que Espronceda ofrecía al público; en los poemas examinados en el otro trabajo aludido aquí, se rastrea la visión privada del adolorido poeta.

${ }^{15}$ En sus Impresiones y recuerdos, refiriéndose a la época de 1854 a 1860 , Julio Nombela apunta: «Este señor D. Narciso era hermano de D. Patricio, político y literato de gran celebridad [...], y según se decía entre los escritores de aquel tiempo, después de haber sido heredero de Espronceda en el amor de la célebre Teresa, se había casado con la hija de ésta y de su amigo; con la interesante Blanca, a quien como todos los vates de mi tiempo deseé conocer» (Impresiones y recuerdos, Madrid, Casa Editorial de "La Última Moda", 1909-1911, 4 vols., t. II, p. 173. Fue precisamente en el año 1854 en el que Blanca de Espronceda se casó con Narciso de la Escosura. Narciso tuvo hijos con Teresa y con su hija Blanca. 
que nunca muere / y está en mi corazón; un lastimero, / tierno quejido que en el alma hiere, / eco suave de su amor primero, / jay! de tu luz en tanto yo viviere, / quedará un rayo en mí, blanco lucero, / que iluminaste con tu luz querida / la dorada mañana de mi vida» (p. 235, vv. 1780-1787).

Pues lo que en realidad añora Espronceda es la pérdida de su imagen idealizada de sí mismo, su aspiración a vivir un gran amor en este miserable mundo, su voluntad de cortar ante los ojos de sus admiradores la figura de elegante dandy y amante romántico. Debido a lo personal de tal pérdida, las lágrimas de Espronceda son interiores: «le quedó al corazón sólo un gemido, / iy el llanto que al dolor los ojos niegan, / lágrimas son de hiel que el alma anegan!» (p. 222, vv. 1505-1507); «...un corazón, que penas a millares, / jay! desgarraron, y que ya no llora» (p. 229, vv. 16491650); «dentro del pecho mi dolor oculto» (p. 238, v. 1837); «...mi dolor profundo» (p. 239, v. 1850). El llanto denegado, invisible, el dolor del personaje autobiográfico Espronceda es de la misma variante que experimentan en cierta ocasión Macías y Elvira en El doncel de don Enrique el Doliente, de Larra: «no lloraba ya Elvira, no derramaba una lágrima Macías. En las grandes situaciones de la vida no halla salida el llanto. La inmovilidad del mármol, el estupor de la postración, son los caracteres de las emociones sublimes. El silencio entonces es elocuente, porque no hay palabras en ninguna lengua ni sonidos en la naturaleza que pinten el amor en su apogeo, que expliquen el dolor en toda su intensidad» ${ }^{16}$. «El dolor es la suprema emoción de que es capaz el hombre - comenta Pedro Enríquez Ureña-, y es a la vez el tipo y medida de todo gran arte» ${ }^{17}$. Salta a los ojos la motivación en gran parte egoísta del dolor del personaje autobiográfico del Canto a Teresa, mas esto no obsta para que ese dolor tenga en sí el tono y el atractivo de la sinceridad, y sea uno de los grandes valores estéticos del poema.

La historia de los amores de Espronceda y Teresa, la culpa de Teresa y su papel de tentadora se recapitulan con unos símbolos tan interesantes como transparentes. Sobre ese amor que al mismo amor adora, comenta Espronceda que también «es el amor que recordando llora / las arboledas del Edén divinas, / amor de allí arrancado, allí nacido, / que busca en vano aquí su bien perdido» (p. 228, vv. 1632-1635). Quiere decirse que todos los que buscamos nuestro ideal en el amor no hacemos más que representar repetidas veces la tragedia de Adán y Eva. Porque fue de hecho esa primera mujer, Eva, quien privó al poeta, a todos los hombres, de la realización de su aspiración a un afecto sublime. Todas las mujeres, Teresa

16 Mariano José DE LARRA, El doncel de don Enrique el Doliente, ed. de José Luis Varela, Letras Hispánicas, 76, Madrid, Cátedra, 1978, p. 328.

17 Citado por José Deleito Y PIÑUELA, El sentimiento de tristeza en la literatura contemporánea, Barcelona, Editorial Minerva, s.a. [hacia 1920], p. 227. 
entre ellas, son nuevas Evas; y he aquí cómo explica Espronceda la reacción en cadena a través de tantos siglos y milenios: «sí, que el Demonio, en el Edén perdido, / abrasara con fuego del profundo / la primera mujer, y ¡ay! aquel fuego / la herencia ha sido de sus hijos luego» (p. 232, vv. 1711-1715). Luego, en la octava siguiente tenemos una refundición romántica de la triste historia de los que se amaron en el Edén: «Brota en el cielo del amor la fuente / que a fecundar el universo mana, / y en la tierra su límpida corriente / sus márgenes con flores engalana; / mas ;ay! huid: el corazón ardiente / que el agua clara por beber se afana, / lágrimas verterá de duelo eterno, / que su raudal lo envenenó el infierno» (p. 232, vv. 1724-1731).

Se propone una comparación entre la fuente del amor, imagen poética romántica, y el fruto del árbol de la ciencia del bien y el mal de la Biblia. En fin: Espronceda, nuevo Adán, es llevado a su perdición por su nueva Eva, Teresa. De igual modo que Eva tentó a Adán para que comiera de la manzana prohibida, Teresa tienta a Espronceda llevándole a probar las aguas infernales del amor prohibido, que su raudal lo envenenó el infierno. Al menos así lo quiere creer el poeta, pues en tal versión de lo sucedido tiene su disculpa. También es en este contexto donde se establece uno de los fascinantes lazos entre el poema largo El diablo mundo y el poema interpolado Canto a Teresa, que Espronceda niega sólo por coquetería; pues el protagonista del poema largo se llama Adán, y mientras que el adánico personaje autobiográfico del Canto representa a Adán en la pérdida de su inocencia, el viejo Adán de El diablo mundo, milagrosamente convertido en joven cándido, que con escándalo de todos sale desnudo a la calle, representa la recuperación de la inocencia y la inversión parcial de la historia bíblica ${ }^{18}$. Uno se mancha con el pecado original; el otro se absuelve de esa secular mácula.

Mas no hemos agotado el tema de la fuente del amor y su tratamiento en el Canto a Teresa. Espronceda inserta, a lo largo del poema, alusiones a fuentes, ríos, mares y otras aguas a fin de insistir con ecos en su curiosa explicación biblica - disculpa - del escandaloso fracaso de unos amores antes tan ideales. Estos líquidos recordatorios de la corrupción de un inocente por una tentadora, que le llevó a beber de la fuente del amor prohibido, se hallan en las octavas $1,3,4,5,13,17,21,25,35$ : anegan, fuentes, mar, mar del mundo, fuente, mana, río, aguas del sereno río, aguas

${ }_{18}$ Sobre este y otros ingeniosos enlaces entre el Canto a Teresa y El diablo mundo, véase el brillante artículo de Alexander SELIMOV, «La historia de dos Adanes: La estructura integral de El diablo mundo», en Hispania, t. 78 (1995), pp. 773-779. En el drama Don Juan Tenorio, de Zorrilla, se dan símbolos religiosos y elementos rousseaunianos que permiten interpretar esta obra como una refundición de la historia de Adán y Eva a la inversa. Véase. SEBOLD, Trayectoria del romanticismo español, pp. 66-70; o bien, mi artículo «Don Juan en el Edén», $A B C$, domingo, 29 de agosto de 1993, p. 60, 
cristalinas, manantial, estanque, aguas corrompidas, olas. No tomo en cuenta, desde luego, las palabras de esta índole que se hallan en los pasajes donde se hace la comparación entre la historia edénica y la de Espronceda y Teresa.

En armonía con la temática del Canto a Teresa y su interpretación como nueva versión de la historia amorosa del Libro de Génesis, el poema podría editarse dividiéndolo en cuatro partes, con sendos títulos: I. Adán en el paraíso, abarcando desde la octava 1 hasta la 12 inclusive; II. Adán conoce a la mujer ideal, Eva, que incluiría solamente las octavas 13 a 18, pues en el mundo de Espronceda dura poco la visión idealizadora; III. La caída de Adán y Eva, que comenzaría con la octava 19 y terminaría con la 30; y por fin, IV. El paraíso recordado y Teresa castigada, que tendría su principio en la octava 31 y contendría el resto del poema interpolado. Con cierta frecuencia, en otro tiempo, el Canto a Teresa se editaba aparte de El diablo mundo, y se adaptarían mejor a semejante edición los posibles títulos de partes propuestos aquí. Bécquer se proponía preparar una edición suelta del Canto a Teresa, con una sola octava en cada página, cada una de ellas con diferente orla a dos tintas alusiva a su contenido episódico ${ }^{19}$. Mientras escribo esto, miro una edición, de formato pequeño e íntimo, del Canto a Teresa, realizada en La Habana, por el poeta e impresor español Manuel Altolaguirre, en 1939, para la simpática colección «El Ciervo Herido». En la edición de Altolaguirre se estampa una sola octava en cada página, en su parte superior, dejándose el resto de cada hoja en blanco, como si fuera para recoger las lágrimas que el lector derramara por los conmovedores detalles contados en esa octava. Al final de su preliminar de una sola hoja, M. A. [Manuel Altolaguirre] observa con acierto que «en este canto de amor Teresa es el ciervo herido».

En el romanticismo mundial no hay obra más hermosa ni a la vez más odiosa que el Canto a Teresa. A pesar del detestable concepto de la mujer que presenta, el poema se salva como obra maestra por su hermosa expresión de la nostalgia, por sus hermosas imágenes y por su hermosa versificación. El estar enteramente compuesto en octavas reales, lo tiene en común el Canto a Teresa con epopeyas cultas como La Araucana (15691589), de Alonso de Ercilla y Zúñiga, El Bernardo (1624), de Bernardo de Balbuena, El Pelayo (1754), de Alonso de Solís Folch de Cardona Rodríguez de las Varillas, conde de Saldueña, y El Pelayo (sin concluir),

19 Sobre esto, véase la lista de Proyectos literarios que dejó BÉCQUER, en Obras completas, 13. ${ }^{\mathrm{a}}$ ed., preparada por Dionisio Gamallo Fierros, Madrid, Aguilar, 1969, pp. 1232-1233. Sobre la influencia del Canto a Teresa en las Rimas de BÉCQUER, véase Introducción a BÉCQUER, Rimas, ed. de Sebold, pp. 138-141 y passim. Sobre el influjo del canto I de El diablo mundo en una rima concreta, véase mi artículo «La rima $\mathrm{V}$ de Bécquer en segunda persona», Boletín de la Real Academia Española, t. LXXV (eneroabril 1995), pp. 1-23. 
del propio Espronceda. La selección del metro épico para su poema de tema amoroso personal, en cuarenta y cuatro octavas reales - que es, además, un Canto como tantos poemas épicos-, es el modo sutil del poeta de declarar que el dolor ocasionado por sus amores con Teresa merece la atención del gran público.

Pues un poema épico se compone con el propósito de ensalzar hechos de armas dignos de la admiración universal. Las hazañas que Espronceda glorifica son sus poco felices combates en la liza del amor. Pero una de las particularidades de este nuevo género de epopeya es que en él se prefiere la derrota a la victoria, porque con aquélla se abre paso a la expresión de infinitas emociones subjetivas, y éstas son las predilectas del romántico, que es un fiel devoto del panteísmo egocéntrico, según el cual todo el universo es el espejo de su adolorida alma. El romántico, por su mismo carácter, aspira a cantar sus cuitas en todas las calles, plazas, callejuelas y plazoletas del mundo, pues solicita la conmiseración, la conlacrimación, de todos sus semejantes. Se trata de una variante de esa característica del romántico que es conocida como la sed de lo infinito. Para que nos entendamos, vaya otro ejemplo. En Don Álvaro o la fuerza del sino, no por su desgracia deja doña Leonor de atender a la fama de su desgracia: «Mi desgracia en toda España / suena de modo distinto» ${ }^{20}$. Espronceda ha dotado a este afán romántico de su más adecuada expresión métrica: la octava real. También debió buscar otro título más conforme con la realidad de su nuevo modo de epopeya: verbigracia, Canto a mis cuitas de amador - uno de los títulos que Cadalso ideó para sus poesías fue Alivio de mis penas-; porque el Canto a Teresa tiene poco de elogio de Teresa y poco de lamento por la muerte de Teresa.

\footnotetext{
20 DUQUe DE RIVAS, Don Álvaro o la fuerza del sino, ed. de Miguel Ángel Lama Biblioteca Clásica, 91, Barcelona, Editorial Crítica, 1994, p. 121.
} 